\title{
From Idealism to Pragmatism
}

A Matter of Evolution

Willem A. deVries

\section{(2) OpenEdition Journals}

Electronic version

URL: http://journals.openedition.org/ejpap/1299

DOI: 10.4000/ejpap.1299

ISSN: 2036-4091

\section{Publisher}

Associazione Pragma

\section{Electronic reference}

Willem A. deVries, "From Idealism to Pragmatism », European Journal of Pragmatism and American Philosophy [Online], X-2 | 2018, Online since 11 January 2019, connection on 19 April 2019. URL : http://journals.openedition.org/ejpap/1299; DOI : 10.4000/ejpap.1299

This text was automatically generated on 19 April 2019.

\section{(c) $(1)$}

Author retains copyright and grants the European Journal of Pragmatism and American Philosophy right of first publication with the work simultaneously licensed under a Creative Commons AttributionNonCommercial-NoDerivatives 4.0 International License. 


\title{
From Idealism to Pragmatism
}

\author{
A Matter of Evolution
}

Willem A. deVries

1 Pragmatism has long been recognized to have close ties to Idealism. Indeed, there have been arguments that pragmatism must itself be a form of idealism. ${ }^{1}$ I do not think such arguments hold up, but I would not deny for a second that there is a deep relationship between idealism and pragmatism. I want to tell a story about the changing nature of idealism that makes sense of their relationship without threatening to collapse one into the other. My story is a history, and idealism's history began hundreds of year before pragmatism entered the stage, so I beg the readers' indulgence: it will take me some time to set the table before we are prepared to discuss the relation of pragmatism to idealism. To foreshadow: I take it to be clear that pragmatism has very little in common with the subjective idealism of Berkeley or the problematic idealism of Descartes; the differences between idealism and pragmatism get blurred only because idealism underwent an evolution that so transformed it, not long before pragmatism emerged, that it might seem a small step between them. It was, according to my story, the evolved idealism developed in Germany between 1781 and 1831 that contributed to the formation and development of pragmatism. Yet pragmatism is a large evolutionary step away from idealism, however much it retains and utilizes some of the strengths of late idealistic thought.

\section{Epistemologically-Based Idealism}

2 First off, then, I would like to distinguish two different kinds of idealism. ${ }^{2}$ The distinction I draw here is rooted in the motivations for adopting an idealist position. One kind of idealism arises out of epistemological considerations, and has both negative and positive components. There is a localized skepticism as a negative component, counterbalanced by positive epistemological and ontological commitments in a different locale. Historically, it arises within a Cartesian framework that assumes that we have direct and incontrovertible cognitive access only to our own mental states, often denominated as ideas. Our knowledge of anything that is not an idea or a mental state is, then, at best derivative and probable (this is the negative element), rather than primary and certain. 
Since, on this Cartesian view, our own mental states are supposed (once clearly and distinctly perceived) to be transparent to us, the positive elements of the position are the ontological commitment to the being of ideas and the epistemological commitment to our knowledge of them. If we stop here, we have what Kant attributed to Descartes and called "problematic idealism" (B274).

3 As Kant notes, it is but a further step to declare that our conceptions of non-mental objects are "false and impossible"; it is certainly the case that they are highly complex and that we can generate at least apparent antinomies that beset our conceptions of the non-mental. If we thus strengthen the negative aspect of the position into a strong (though still somewhat local) skepticism, while retaining our commitment to the being of the mental, we get a position that Kant identifies with Bishop Berkeley and calls "dogmatic idealism" (B274).

4 Kant holds, of course, that his own transcendental idealism is neither of these positions. It dispenses with the local skepticism about the material or external world, for the argument of the 'Refutation of Idealism' is that our knowledge of our inner states is interdependent and of equal stature with our knowledge of external or material states of affairs. But Kant's transcendental idealism does not dispense with the skeptical element altogether; rather, it relocates it by drawing a new boundary, not between the inner and the outer, but between the phenomenal and the (really) real. We can and do have knowledge of the phenomenal, which includes both the inner and the outer, but it is all inflected with our own conceptual structure and thus not equivalent to knowledge of a purely mind-independent reality as such, which remains forever out of our reach.

5 Peirce gives us a closely related diagnosis of the idealism that Kant responds to in his 'Refutation of Idealism' and notes the extent to which Kant remains caught in the overall picture that requires some form of direct and immediate presence-based knowledge, which entraps him in another form of idealism. This analysis - admittedly in texts put together by his editors, Hartshorne and Weiss - can be found in volume 1 of his Collected Papers (CP 1.35-39). Peirce sketches there his way out of such idealisms, but that is part of a slightly different story, so I will not pursue it here.

6 Kant denies us any knowledge of a purely mind-independent reality. Yet it does seem a bit odd to call his position a form of idealism, for he is not, in the end, committed to the ontological priority or independence of the ideational, certainly not under a standard interpretation of 'idea.' Concepts (or rather exercises of concepts) and intuitions, his equivalent to the ideas of his predecessors, are phenomenal entities (they are at least in time) that are not themselves items of the really real world of things in themselves. Seen in this light, Kant should have found a different name for his own position. Bishop Berkeley has often been called a "subjective idealist." ${ }^{3}$ This was a label that Kant insisted did not apply to his own position; the main reason for the revisions in the B edition of the first Critique was to distance himself further from Berkeley's subjective idealism. Perhaps Berkeley's position is, in fact, better called an "constitutive idealism," because the only objects recognized in his ontology are minds and ideas; material objects exist only objectively (in the Cartesian sense) in ideas. Then we could free up the label "subjective idealism" to describe Kant's position, namely that all objects of thought and experience are 'tainted' with the structures of our human cognitive framework, so that everything available to a subjectivity is ideal or mind-dependent. On that reading of "subjective idealism," the position does not exclude accepting objective realism as well, that is, believing in the existence of a mind-independent reality. 


\section{Ontologically-Based Idealism}

7 I promised two conceptions of idealism, and I haven't yet discussed the second. This version of idealism is directly metaphysical and is not motivated by any particular epistemological theses. According to this version of idealism, material things and any other things that are not minds or their ideas are somehow lacking in being and therefore not deserving of first-class ontological status. Notice that we could slip the good Bishop Berkeley into this version, for the kinds of incoherence that he thought beset our concepts of material things serve perfectly well to make them unqualified for ontological commitment. But Leibniz is, I think, a purer case of this form of idealism: material objects are merely phenomenal in his fully considered view, because they are merely passive, and anything that is real must be active, something only minds or mind-like items can bring off, in his view. We can think of Leibniz here as taking a cue from Plato: "to be is to have power" (Sophist 247e), ${ }^{4}$ and space, time, and material things don't measure up; thus, they are merely ideal. Hegel adopts a different version of this form of idealism. It turns out, on his dialectical analysis, that material reality and nature do not have the ontological bona fides; they exist in order that spirit may realize itself, and the true measure of the ontologically real is the ability to self-realize. ${ }^{5}$

To the extent that Peirce flirted with what he calls "objective idealism" (CP 6.24-25), I think we should consider this a flirtation with this second form of idealism.

9 This second form of idealism is unabashedly metaphysical, and it assumes that one has a firm grasp of the criterion of being. Furthermore, this criterion cannot be purely formal; it must have some content to it whereby material things in space and time can be distinguished from the minds, ideas, or mental states that really exist. As various forms of materialism, physicalism, or at least naturalism have gained ascendency in recent AngloAmerican analytic philosophy, this form of idealism seems more and more remote, because it seems to be getting more difficult to believe that material things are dependent on the mental rather than the mental being dependent on the material. After all, our investigations of materiality have been yielding interesting, important, and useful results for several centuries now, whereas investigations of the mental or ideal, as such, show comparatively little such progress, at least as of yet. Indeed, much of the progress that has been achieved in the sciences of mind has come from the investigation of the materiality of mind.

\section{The Contribution of the Substance Framework}

As I have said, my story is a historical look at the evolution of idealism. To get a fuller sense of evolution, I am going to cast a glance back to a time before the emergence of idealism, even if it seems like a detour on our road to understanding the relation between idealism and pragmatism.

11 The classical forms of idealism I described in sections 1 and 2 - one a contrast to realism and one a contrast to materialism - were developed within the general framework of the Cartesian approach to mind, and it is important that the Cartesians also employed a substance metaphysics. This is a framework that assumes that the basic entities of the world are substances, enduring objects with various and multiple properties, each such 
object capable of existence on its own - that is, without being the property of some other substance. Each substance has a least one essential property crucial to it that determines its fundamental kind, that is, the conditions of its identity and individuation. This substance framework, in such an abstract formulation, is itself a formal framework; to be able to apply it, one needs to specify what kinds of things are substances, that is, what properties are such as to determine or specify the object possessing them as a substance, a basic object capable of its own existence independent of inhering in yet some other object.

12 A substance framework is not, on its own, sufficient to generate a strong contrast between idealism and realism (the epistemological contrast) or idealism and materialism (the ontological contrast). We need the combination of the framework of substance together with the New Way of Ideas initiated by Descartes and picked up by his successors on both sides of the English Channel. A brief look at the Aristotelian interpretation of the framework of substance makes this clear.

Given Aristotle's hylomorphic construal of the substance framework, one cannot generate a clash between materialism and idealism, because hylomorphism does not generally allow for minds, for psychai, to be independent existences separable from the matter they inform. ${ }^{6}$ Minds are not the kind of thing that could be a primary substance; psychai are forms that require a matter to inform. An Aristotelian framework is patently realistic, because it clearly recognizes the existence of mind-independent objects. Within that framework, the notion that the fundamental reality of things generally is ideal or mental cannot get off the ground, because (1) not every form is a form of psyche, so there are things uninfected with the mental, and (2) the Aristotelian stands by the claim that it is the same thing that thinks that walks, so material reality is unexpungeable.

Only once the Aristotelian hylomorphic framework is abandoned can one generate a real clash between idealism and materialism. Minds have to be thought of as themselves substantive entities that stand in contrast to and independent of material entities. Only then do we get the either/or that makes idealism versus materialism seem like a choice one is forced to make. Traditionally, we think of Descartes as responsible for this move.

We could rehearse a related set of arguments to show that it is equally difficult to generate an epistemologically-based idealism/realism contrast, given Aristotelian epistemology, but we will not take the time to do that here.

16 This is significant in our context here because, while Peirce was not opposed to employing the substance framework, with some adaptations, Dewey is far less enamored of that framework, and thus well inclined to dismiss the contrasts essential to a determinate idealistic doctrine - the contrasts to the real and to the material - as misleading and confused, just as Aristotle might have.

\section{Hegel as Realist and Idealist, but not a Pragmatist}

17 So the realism/idealism and materialism/idealism disputes were central concerns in early modern philosophy from Descartes up to Kant, and we can find both epistemologically and metaphysically motivated versions of idealism in this period. We have briefly noted that Kant's transcendental idealism is perhaps less than perfectly named, but I now want to argue that in German Idealism in general (though I will focus solely on Hegel) the 
realism/idealism/materialism contrast gets complicated enough that it is far from obvious that it remains a genuine contrast between opposing metaphysical views.

First off, we need to recognize in Hegel's philosophy the significance of the distinction between subjective spirit and absolute spirit. There is, in Hegel's view, no reality external to absolute spirit, but there is a great deal of the real world that is quite independent of subjective spirit (and subjective spirits).

Let us also be clear that Hegel is an epistemological realist. That is, he certainly believes that individual subjective spirits - people like you and me - know facts and objects that exist quite independently of them. To the extent that Hegel is, indeed, an idealist, his idealism is not motivated by any skepticism about our ability to know material reality or things external to our mind.

incipal Hegelian doctrine we need to understand to make some further progress in thinking about Hegelian idealism in this context is the proclamation that "everything hangs on apprehending and expressing the truth not merely as substance but also equally as subject" (PhG I17). This sounds like Hegel is just picking up the concept of substance and adding to the idea that substance is what there primarily is the further qualification that it is subject as well - but, of course, this means radically re-thinking the notion of substance.

Before the Post-Kantians, it was easy to think of substance merely as something underlying and supporting the properties that inhere in it. Those properties may be inactive, like extension, or active, like thinking. As I've mentioned, Leibniz was committed to the fundamentally active nature of substance, and in that, he prefigured the Post-Kantians. Kantian (phenomenal) substance is matter, but he thought of matter along Boscovichian lines, that is, in terms of centers of attractive and repulsive forces, and thus not as primarily passive. ${ }^{7}$ For most of the early modern period, substance as such had no particular material (that is, non-formal) characteristic. That is what makes Locke's characterization of it as a "something I know not what" trenchant. ${ }^{8}$

Hegel's dictum that substance is subject puts a very different face on the matter. For he does not mean subject in the sense of the subject of a judgment, but in the sense of the subject who judges. And his conception of subjects of judgment and experience is not a conception of some 'inner space' through which various otherwise unconnected representations, whether impressions or ideas, parade. Taking a clue from Kant's notion of a unity of apperception, Hegel thinks of a subject as an active unifying of multiple items (some of which are indeed representations) received, recollected, generated, and even rejected by it. These items, however, are themselves dependent on their occurrence within the unity of the subject: they cannot be intuitions, representations, or thoughts prior to or independent from their place in the overall process of self-unification of the subject, which self-unification is not independent from its fit within a larger environment or context. Because the internal states and the external actions of subjects can be what they truly are only within the context of their overall unification, which itself produces the subject, Hegel thinks of subjects as self-realizing agencies. But finite individual subjects are not capable of self-realization all on their own. The particular unifying activities engaged in by the various subjective spirits make full sense only within a larger unifying activity that occurs at a level above that of the individual subjective spirit. In fact, there are several levels here: individual subjective spirits make sense only insofar as they embody the unifying practices of social community, and the whole shebang, Hegel 
holds, makes sense only as a part and aspect of the self-realizing activity of Absolute Spirit. Hegel's criterion of being is self-realization, and the Absolute is the ultimate, cannot-fail self-realizer.

Hegel thus turns out to be an absolute idealist because reality itself has the kind of being that minds possess. This is not because minds, that is, subjective spirits, are all that really exist, but because reality - everything that is - makes sense, is what it is, as an element in a mind-like structure. But in that case the real/ideal contrast is, essentially, overcome; that is, it is no longer a consequential distinction. The Hegelian view also defangs the contrast between idealism and materialism. Materialists, Hegel thinks, are too focused on what things are made of - but he does not deny that people and communities exist in complex dispositions of material things. Just as Aristotle thought that forms must be realized in matter, Hegel believes that it is necessary that the Absolute realize itself in or through a material nature.

I have described elsewhere some of the commonalities shared by Hegel and the pragmatists. ${ }^{9}$ These include an endorsement of epistemological realism, a rejection of the nexus of doctrines we can call "Cartesianism," a rejection of the apriori, the employment of a rich conception of experience, an inferentialist/functionalist theory of concepts, the sociality of reason, and, last but not least, an emphasis on centrality of agency expressed within an external, spatio-temporal world. The discussion here of Hegel's deconstruction of the realism/idealism/materialism distinction can be added to the list of what he shares with the pragmatists. Despite all these shared commitments, Hegel is not a pragmatist. I go into more detail in the article mentioned above, but for our purposes the relevant difference concerns the status of the ideal. For Hegel the ideal is the real; the pragmatists, in contrast, the notion of the real is itself an ideal. Hegel's worldview is ultimately teleological at its very heart; nature is there for the sake of spirit. The telos recognized by the pragmatists emerges from the blind operations of nature; spirit, if we can call it such, emerges from nature, but does not itself draw nature into being.

\section{Pragmatism, The Real, and The Ideal}

There are plenty of references to realism, idealism, materialism and the like among the pragmatists. But, given their rather ginger attitude towards metaphysics generally, the references are almost never straightforward endorsements or rejections. I suggest we look, not at what they say about the 'isms,' but about reality itself. Peirce starts off with a fairly traditional approach to reality: "we may define the real as that whose characters are independent of what anybody may think them to be" (Peirce, CP 5.405). But when combined with the pragmatic maxim, ${ }^{10}$ this definition takes on a different aspect: "The opinion which is fated to be ultimately agreed to by all who investigate, is what we mean by the truth, and the object represented in this opinion is the real. That is the way I would explain reality" (Peirce, CP 5.407).

It is worth reflecting a bit on this explanation of reality. In the first few parts of this paper I discussed the framework within which the early modern thinkers argued about realism and idealism. Note that this framework is missing in Peirce's dictum. Peirce has moved well beyond the "new way of ideas" that dominated early modern Western philosophy from Descartes up to Kant. Peirce does not adopt the Cartesian assumption that we know our own mental states first and best or that we have some direct, transparent, and incorrigible cognitive relation to our own mental states. He has a much 
more sophisticated understanding of what is involved in the notion of representationality and the conditions for being a representation of something. Furthermore, the notion of substance never rears its head; the issue is not what things are "made out of" or what kind of thing ultimately has which properties, or what the fundamental nature of the substance(s) of the world is. The real is what we represent, the object of representing, and the representings are themselves real only to the degree they also are objects of the fated final opinion.

One thing to note about Peirce's characterizations is that realism pretty much falls out of his position automatically. ${ }^{11}$ The real is the object of our representations - this means that there could hardly fail be something real, unless our representations turn out not to be representations at all and have no objects whatsoever. Of course, Peirce does not mean that the real is the object of just any or all our representations. It is the object of just those that are the enduring product of inquiry, those that are responsive and responsible to sensory experience as well as some other cognitive constraints. We can tell whatever stories we want; we can entertain concepts and thoughts of all kinds, but we are committed to accept as representations of the real only those beliefs that get fixed as a result of the practice of inquiry, properly conducted. And once we've gotten clear that ideas or representations, as the medium of thinking, are not thereby also always the object of thought (though they may also sometimes be the object of thought), there is little temptation left to believe that ideas are all that exist.

Still, it seems Peirce's characterization of the real cannot be divorced from the epistemic or the mental. The tie to the epistemic, however, is not in virtue of any connection to certainty, intuitive truth, or revelation, but simply by a connection to truth and the idea that there are proper ways or methods by which to seek the truth. But to be clear, the connection to truth does not itself support any kind of idealistic reading. Is there an idealism hidden in the idea that something is "fated" to be agreed to by all who inquire, because there would have to be some hidden intellectual agency controlling such fates? There is no reason to believe that what Peirce has in mind is any more portentious than what is going one when one says "Well, they're bound to find out sooner or later that their boy has stopped going to classes and run off with the circus."

Peirce's characterization of the real is tied to the mental because it refers to opinion and representation. These are the proper subjects of the truth predicate. What is most striking, however, is that both truth and reality, in Peirce's explanation, are regulative ideals. Truth is not a thing and it is not a relation, not even of correspondence. It is the general aim of inquiry, and its particulars are identified by inquiry properly conducted; that is, it is belief properly fixed. Thus, coming into possession of the truth (at least with any reliability) depends on proper conduct or practice: that is a basic tenet of pragmatism. 'Methods' such as revelation or authoritative pronouncement turn out not to be proper forms of the conduct of inquiry.

Frankly, it has never made much sense to me that pragmatism has been accused of falling into idealism. But we can reconstruct what some of the reasoning must have been. One argument is an argument from historical influences: Peirce was expressly influenced by Kant and admits as well to influences from Schelling and Hegel. ${ }^{12}$ They are all idealists of some stripe, so Peirce is as well. A similar argument might apply to Dewey, given his Hegelian roots. But such arguments are notoriously weak: Students, unlike apples, often do fall far from the tree, and it is a good thing too - otherwise philosophy could never really evolve. 
31 A different argument would rely on the fact that reality is defined in terms of truth and representation, which are, in turn, regulative ideals. Because of this, it might look like our mental states and activities play an important constitutive role in reality. But it is, of course, far from Peirce's (and from Dewey's) mind that we somehow constitute reality (as opposed to experience) by representing it in some particular way. The pragmatist believes that, as far as epistemology goes, our minds are fitted to the world by a combination of evolution and good epistemic practice. The pragmatist does not believe that, epistemologically, the world is fitted to, much less made up from, our minds. ${ }^{13}$

\section{Pragmatism's Evolutionary Step}

The influence of idealism on pragmatism cannot be denied. A modicum of reflection quickly reveals several central tenets of (particularly German) idealism that the pragmatists accepted and (mostly) made their own. I mentioned above (1) an endorsement of epistemological realism, (2) a rejection of the nexus of doctrines we can call "Cartesianism," (3) a rejection of the apriori, (4) the employment of a rich conception of experience, (5) an inferentialist/functionalist theory of concepts, (6) the sociality of reason, and, last but not least, (7) an emphasis on centrality of agency expressed within an external, spatio-temporal world. I would add here (8) articulated holisms of concept and justification.

33 I have discussed these connections between Hegel and the pragmatists elsewhere. ${ }^{14}$ So I will not go into the details of each connection here. Rather, I want to make a more general observation. At a level of high abstraction, we can say that what is shared by the German Idealists and the pragmatists is a commitment to the priority of system. This separates them decisively from the empiricist tradition, at least through Mill and his godson, Russell. Atomistic approaches to problems have proven very productive in the natural sciences, and this has been a steady source of inspiration for standard forms of empiricism, which held on to the idea that knowledge could be acquired in piecemeal, independent atoms and then assembled and elaborated into the structure we call empirical knowledge. The empiricists also held that metaphysics, to the extent that it was possible at all, must also be a structure of atoms and molecules.

Late idealistic thought is a reaction against the overweening atomism of the empiricists. Things do not make sense independently of some context. Kant recognized that representations, in particular, have sense only in the context of a whole representational system, and this imposes certain constraints on anything that counts as a representation. The whole "new way of ideas" blithely assumed that ideas were somehow intrinsically representational: what they represented, their 'content,' was somehow built right into their fabric without regard to their relations to the things they represented (if such things existed at all) or even, in the case of simple ideas, their relations to other ideas. When Kant asked the question, "What is the ground of the relation of that in us which we call 'representation' to the object?," 15 he moved beyond the new way of ideas and opened up a new field of inquiry that we are still plowing. Kant saw that the representationality of mental acts depended crucially on their bearing systematic relations to other mental acts; by the time we reach Hegel that insight has been extended. Our ability to think depends not only on our thoughts bearing systematic relations to other mental acts of ours, but also on their bearing systematic relations to the mental acts of others and 
systematic relations more generally to the world within which the whole shebang proceeds.

Kant sees a connection between systematicity and design, but it is not a straightforward connection. He does not think that we can infer from the apparent systematicity of the world to its having been a designed creation. But he does think that we need to think of the world as if it is designed in order to be able to discover the often-masked systematicity that must be there if we are to be able to cognize the world. The idea of a well-designed world functions as a regulative ideal informing, inspiring, and constraining our cognition.

This complex of ideas undergoes further transformation in Hegel. He has, for instance, no patience with regulative ideals: A purpose that is forever and in principle beyond achievement is no real purpose at all. Hegel also does not draw the same connection between systematicity and design that Kant does. Kant thinks that design has to be someone's design, the creation of a thinking thing. Hegel's more naturalistic (and more Aristotelian) interpretation of teleology accepts the notion that there can be and is a natural teleology that is not a form of trying to realize some desire, given one's beliefs, but something more primitive and more widespread: self-realization, as in an organism. ${ }^{16}$ Hegel's notion of self-realization, however, is still modeled on Kant's conception of the self-constituting unity of apperception; that is, the model on which Hegel conceives the overall systematic unity necessarily found in a world capable of being known from within remains the unity of a mind, now magnified to the ultimate self-realizer, the Absolute.

I think the pressures not only to recognize the necessity of systematicity but also to account for it operate just as strongly in Peirce and Dewey as they do in Kant and Hegel. Peirce is certainly even clearer than Kant and Hegel were about the need for systematicity if one is going to make sense of the representationality of thought and our capacity to know the world within which we live. But the model for the nature and origin of that systematicity shifts significantly. Peirce's new model, one not available to either Kant or Hegel, was also adopted by Chauncey Wright and picked up by the other pragmatists: evolution, not mind. Darwin displaces God, not through apotheosis, but by giving us a model of designerless design that makes the hypothesis of God, as Laplace famously pointed out, not necessary, even if one recognizes the need for systematicity in human knowledge and the world it knows.

One might think that Darwin's model has distinctive limits: doesn't it apply only to organisms? If that is the case, then it will not account for a more general systematicity in the world, for the realm of the organic is quite limited, as far as we know. Peirce, however, applies the model far more broadly, telling us that "the only possible way of accounting for the laws of nature and for uniformity in general is to suppose them results of evolution" (Peirce, CP 6.13). This remark is not a one-off in Peirce's work. He tells us elsewhere that he has been "led to the hypothesis that the laws of the universe have been formed under a universal tendency of all things toward generalization and habit-taking" (Peirce, CP 7.515), which he argues is precisely such as to lend itself to evolutionary development over time. Peirce was unabashed in making this grand metaphysical hypothesis, and I don't know of similar speculations on the part of other classical pragmatists, but the pressures Peirce is responding to in speculating about the explanation of the uniformity and systematicity of nature are, it seems clear to me, just those that drove Kant to the Ideas of Reason and Hegel to the Absolute. 
But what a difference! In Peirce's picture, things emerge from inexorable, natural processes, not from the plans or designs of some super-powerful intentional agent, and not from some divine but organic process that leaves us wondering where the original seed might have come from. Peirce's view is not in any interesting sense an idealism, even though it preserves a great many of the features characteristic of German Idealism. But in Peirce's version, these features are not accounted for by some top-down explanation that presupposes a grand unifier; they arise bottom-up from smaller, constrained, interactive processes filtered through natural selection. The unity arises from the process itself; it does not lie in any goal or final cause.

It is also revealing to recognize that the shift to evolution as the systematizer helps account for the emphasis on practice in pragmatism. The system of the world is not preordained, either by God's plans or by independent, pre-existing metaphysical natures: it must be created and realized in medias res, as it were, emerging in history from the simplest of beginnings and elaborating itself into the world and us, the knowers of that world. The pragmatic vision is a vision in which activity moves to the forefront in every case, for the world, like us humans, is busy making itself in the course of time. The pragmatist's image of a self-constituting world containing self-constituting thinking beings capable of cognizing that world is not, in my view, all that different from the Hegelian view, but the historical and causal underpinnings at work in the processes of self-constitution are so very different.

41 I have argued that by the early xixth century, idealism as a doctrine no longer stood in clear contrast to its nominal rivals, realism and materialism. But that does not mean that the terms and the contrasts between them became meaningless. There is a good sense and good reason to call Hegel an idealist; there is equally good sense and reason to deny that label to Peirce and Dewey, despite the fact that the larger structures of their views are deeply similar. There is a problem with such descriptions only when one loses sight of the complexity such simple terms often mask.

\section{BIBLIOGRAPHY}

BUROKER Jill Vance, (1972), "Kant, the Dynamical Tradition, and the Role of Matter in Explanation," PSA: Proceedings of the Biennial Meeting of the Philosophy of Science Association, vol. 1972, 153-64.

CoLvin Stephen S., (1905), "Is Subjective Idealism a Necessary Point of View for Psychology?," The Journal of Philosophy, Psychology and Scientific Methods, 2 (9), 225-31. doi:10.2307/2011704.

DeVries Willem A., (1991), “The Dialectic of Teleology,” Philosophical Topics, 19 (2), 51-70.

DEVRIES Willem A., (in press), “Hegel's Pragmatism," in M. Bykova \& K. Westphal (eds.), The Palgrave Hegel, London, Palgrave Macmillan.

DEWEY John, (1906), “Experience and Objective Idealism,” The Philosophical Review, 15 (5), 465-81. doi:10.2307/2177753. 
HAACK Susan, (1976), “The Pragmatist Theory of Truth," The British Journal for the Philosophy of Science, 27 (3), 231-49, [jstor.org/stable/686121].

HEGEL Georg Wilhelm Friedrich, (1969), Hegel's Science of Logic, transl. by A. V. Miller, New York, Humanities Press.

HEGEL Georg Wilhelm Friedrich, (1977), The Phenomenology of Spirit, transl. by A. V. Miller, Oxford, Oxford University Press. (Cited by paragraph number.)

KANT Immanuel, (1998), Critique of Pure Reason, transl. by Paul Guyer \& Allen W. Wood, Cambridge, Cambridge University Press. (References use the standard citation format, in which ' $A$ ' denotes the pagination in the first edition and ' $\mathrm{B}$ ' the pagination in the second.)

KANT Immanuel, (1999), Correspondence, transl. and ed. by Arnulf Zweig, Cambridge, Cambridge University Press.

LOCKE John, (1975), An Essay Concerning Human Understanding, ed. by P. H. Nidditch, Oxford, Oxford University Press.

PEIRCE Charles S., (1960), Collected Papers, 8 vols, ed. by C. Hartshorne \& P. Weiss, Cambridge, MA, Harvard University Press. (References are to volume number, then paragraph number.)

PLATO, (1921), Theaetetus. Sophist, transl. by Harold North Fowler, Loeb Classical Library 123, Cambridge, MA, Harvard University Press.

RYDER John, (1988), "Pragmatism as Idealism,” The Journal of Speculative Philosophy, 2 (4), 317-22.

WARREN Daniel, (2001), “Kant's Dynamics," in Eric Watkins (ed.), Kant and the Sciences, Oxford, Oxford University Press, 93-116.

\section{NOTES}

1. See for instance, Colvin 1905; Ryder 1988. Peirce himself tells us "the one intelligible theory of the universe is that of objective idealism, that matter is effete mind" (CP 6.25).

2. The distinction I draw here might be similar to the distinction Dewey hints at in "Experience and Objective Idealism" between epistemologically-based and cosmologically-based idealisms. But Dewey doesn't say enough to be sure of the extent to which our distinctions coincide. See Dewey 1906.

3. This characterization can often be found in the more popular references, such as the Encyclopaedia Brittanica or Wikipedia. See, e.g., [britannica.com/topic/subjective-idealism]; [ en.wikipedia.org/wiki/Subjective_idealism]; [philosophynotes.net/philosophy/idealism/ idealism-forms-of-idealism-with-criticisms/132].

4. Plato. The Sophist, cited by the traditional Stephanus numbers. The translation in the Loeb Classical Library is "For I set up as a definition which defines being, that it is nothing else than power" (Plato 1921).

5. For instance "The idealism of philosophy consists in nothing else than in recognizing that the finite has no veritable being" (SL 154; 5, 172). Of course, the full story in the case of Hegel - why self-realization is the mark of true being - is vastly more complex than this, but as a first approximation, we can live with this characterization.

6. I will just ignore the apparent separability of active reason for the moment.

7. See, for instance, Buroker 1972; Warren 2001.

8. Locke (1975, Bk. II, Ch. 23, §2).

9. deVries (in press). 
10. "Consider what effects, that might conceivably have practical bearings, we conceive the object of our conception to have. Then, our conception of these effects is the whole of our conception of the object"(Peirce, CP 5.402).

11. For a fuller view of Peirce's realism, including its historical development, see Susan Haack (1976: 241): "Peirce frequently stresses that Reality is independent of human beliefs about it. Nonetheless, he manifests some embarrassment with his notion of Reality, since, as he is well aware, he can not prove that an external independent Reality exists. As he puts it: since he uses the idea of Reality as the foundation for his theory of inquiry, he cannot use that theory show that there is such a thing as Reality."

12. For example, Peirce mentions that he "devoted two hours a day to the study of Kant's Critic of Pure Reason for more than three years, until [he] almost knew the whole book by heart, and had critically examined every section of it" (CP 1.4). He also makes the explicit claims that (1) "My philosophy resuscitates Hegel, though in a strange costume" (CP 1.42), and (2) "I am a Schellingian, of some stripe" (CP 6.605).

13. But, of course there is a sense, and a perfectly good one, in which the world gets fitted to our minds - we are agents who seek to conform the world to our wishes (or at least our needs): that is the practical sphere. It is clear to me that, for the pragmatist, the practical sphere is finite and contained within a wider reality. We do not constitute reality altogether by means of our practical activity, but presuppose access to an already constituted reality within which we strive to achieve ourselves and our projects. Thus, I take it that there is no argument from a pragmatic view of our activity as agents to the claim that pragmatism is a form of idealism.

14. deVries (in press).

15. Letter to Marcus Herz, February 21, 1772. In Kant (1999: 133).

16. I have laid out my interpretation of Kant's and Hegel's differing approaches to teleology in deVries 1991.

\section{ABSTRACTS}

Pragmatism has ties to Idealism; it has even been accused of being a form of idealism. I tell a story about the changing nature of idealism that makes sense of its relationship to pragmatism without threatening to collapse the two. My story is a genealogy that begins well before pragmatism shows up. Pragmatism has very little in common with the subjective idealism of Berkeley or the problematic idealism of Descartes; the differences between idealism and pragmatism get blurred only because idealism underwent an evolution transforming it into something primed to influence and maybe bleed into pragmatism. It was, according to my story, the evolved idealism developed in Germany between 1781 and 1831 that contributed to the formation and development of pragmatism. Yet pragmatism is a large evolutionary step away from idealism, however much it retains and utilizes some of the strengths of late idealistic thought. 
AUTHOR

WILLEM A. DEVRIES

University of New Hampshire

willem.devries[at]unh.edu 